\title{
Estimates of Changes in Real Wages in Poland During the 1960s
}

"The productive effort of society," Communist mythology avers, "has as its goal the provision of increasingly abundant amounts of consumer goods. Moreover, that is the ultimate aim of all production. It should be noted that in a socialist economy, in contrast with systems based on private ownership of the means of production, it becomes a direct goal." It is also said that "the aim of the socialist economy is full satisfaction of the needs of the population."1 One would expect that the fulfillment of this aim would be accompanied by a substantial rise in real wages. The purpose of this note is to check whether that logical conclusion applies to changes in real wages in Poland, by comparing two recent independent estimates-one by W. Krencik, published in Gospodarka Planowa, the Polish economic journal devoted to problems of planning, and the other by the present writer, published in Soviet Studies. ${ }^{2}$

The relevant section of Krencik's article begins with the regret that the Polish Central Statistical Office has failed so far to publish data that make it possible to calculate changes in consumption with any precision. Official figures for real wages in the socialized sector during the 1960-69 period (obtained by using the cost-of-living index as a deflator of money wages) indicate an annual rate of increase of about 1.5 percent, although the results differ from source to source. Krencik decided to make his own estimate for the period 1961-69, limiting it to private consumption out of personal incomes -that is, excluding "social consumption." Private consumption grew by less than the almost 5 percent annual growth of aggregate consumption because the so-called social consumption component (education, health, social security, etc.) grew faster than average. Krencik therefore estimated the private consumption growth rate at about 4 percent, or much less than the 6 percent average official rate of growth of national income.

1. K. Ryć, "Produkcja a konsumpcja" [Production vs. Consumption], Nowe Drogi, 1971 , no. 3, p. 123 (Nowe Drogi is the ideological monthly of the Communist Party). E. Wiszniewski, "Pozycja konsumenta" [The Place of the Consumer], Zycie Gospodarcze, 1971, no. 22 (Życie Gospodarcze is the economic weekly, perhaps the best source of polemics on current economic problems).

2. W. Krencik, "Cele $i$ środki strategii intensywnego rozwoju" [Aims and Means of the Strategy of Intensive Development], Gospodarka Planowa, 1971, no. 4, pp. 206-11. B. Mieczkowski, "Recent Discussion on Consumption Planning in Poland," Soviet Studies, 22, no. 4 (April 1971): 609-11. Supporting footnotes can be found in that publication. 
Two adjustments were then introduced. One was the "rather fast" (about 3 percent a year $)^{3}$ increase in the number of employed persons, among whom part of the 4 percent rise in consumption was distributed as a reward for their contribution to the national product. Part of that rise in consumption was simply the result of more people working, producing goods, and expecting, in exchange, their share of the goods available for consumption. The second adjustment was for the increase in the cost of living by 1.0 to 1.5 percent annually. Thus Krencik arrived at an estimated 1.5 to 2.0 percent annual average rise in real wages. He then tested this result against the statistics for increases in average monthly real wages, demonstrating that their rate of growth did indeed on the average approximate his calculations. From this he concluded, "Although the society achieved a high rate of economic growth, this growth was not reflected in real wages and incomes. If we add to this a lack of adaptation of production to the needs of the population, limitation of outlays on housing construction, other unproductive investments [in the sector rendering economic services to the people], and difficulties connected with the satisfaction of the individual wants of those who did achieve an increase in their incomes, then a picture emerges of the reasons why the society failed to experience the effects of the economic development of the country" (p. 210).

Krencik added two further considerations, the first of which seems quite important. There is abundant statistical proof that during the 1960s the average level of educational preparation rose significantly in Poland. Since the educational level has a direct bearing on productivity and wages, part of the increase in real wages should properly be attributed to the improved quality of labor, rather than to increased reward for a constant quality of the labor expended on production. Krencik estimated the contribution of rising educational level as "at least 1 percent annually," which would leave only about 0.5 percent as the actual rise in real income per worker annually.

Krencik also considered the impact of an increase in the number of executive positions, with more responsibility and a greater number of hours devoted to work. Although such positions raise the average remuneration, they do not signify a rise in pay per unit of effort subjectively evaluated by the employees. Similarly "the number of overtime hours constantly increased," and this in itself contributed to raising average wage paymentsagain, because of the increased productivity it represented. ${ }^{4}$ Krencik went

3. This figure refers to the socialized sector (and not to agriculture), where employment during 1960-69 grew by 35.5 percent. See Krencik, "Cele i środki," p. 208, and Rocznik Statystyczny, 1970 (Warsaw, 1970), p. 64.

4. Krencik appears to combine here two considerations. First, the proportion of executive positions has increased with progressing economic development, and since executives spend more of their time on overtime work than workers do, the proportion of overtime to regular hours must have increased. Second, actual overtime per worker, not necessarily recorded in official statistics, might have increased during the period. 
on to note, "The annual increase of average real wages by 1.5 to 2 percent does not allow for a wage rise. Such a rate of increase merely makes it possible to take into account changes in the structure of qualifications of employees and changes in labor inputs" (p. 210).

The estimate made by the present writer started with an average rise in per capita consumption of 3.5 percent annually during the period 1960-68. The difference between this estimate and Krencik's 4 percent estimate is partly due to my inclusion of the year 1960, when real incomes actually declined by about 1.5 percent, and to the per capita treatment, which Krencik did not include when he considered aggregate personal consumption. I then adjusted the 3.5 percent figure for changes in the overt cost of living of 1 percent-compared with Krencik's 1 to 1.5 percent. However, bending over backwards to be fair, I subsequently abandoned this adjustment and assumed that the 3.5 percent figure had already been so adjusted. Admittedly such an assumption is open to question. But the cost of living also rose in a way that was not reflected in the statistics on price movements-namely, through changes in the assortment of goods offered on the market (higher-priced, but not necessarily higherquality, items were substituted for lower-priced items). Such hidden price rises in Poland had been estimated to amount to 1.6 percent a year during 1960-65 and to 3 percent a year during 1965-67, or roughly 2 percent a year for the whole period. Deducting this 2 percent from the 3.5 percent rise in consumption mentioned above, we find only a 1.5 percent average annual increase in per capita consumption.

I made a further adjustment for the changing age-composition of the population. Because of demographic changes, an increasing proportion of the population entered the labor force. Between 1960 and 1968, production-hence consumption-should have risen in Poland by 2 percent, simply because, on the average, there were more people who were of working age (i.e., who belonged to the economically active population). Furthermore, the so-called labor-force participation rates increased during the 1960s, mainly because a greater percentage of women began to seek employment instead of staying at home. About 1 percent per year in increased production can be attributed to this factor. Thus, because more people of working age were available and because a larger percentage of those available were actually seeking work, labor-force participation increased about 3 percent annually. Given the previously derived 1.5 percent annual average growth in per capita real consumption, this indicates a $\mathbf{1 . 5}$ percent annual decrease in the average standard of living per worker during the 1960s.

It should be pointed out that I did not consider explicitly the last two adjustment factors included by Krencik (improvement in the educational profile of the labor force, and increased personal effort per employee), which jointly amounted to perhaps 1.5 percent or more per year. On the other hand, Krencik 
COMPARISON BETWEEN KRENCIK AND MIECZKOWSKI ESTIMATES Annual rates of change (percent)

\begin{tabular}{|c|c|c|}
\hline Indication of Adjustment & $\begin{array}{c}\text { KRENCIK } \\
1961-69 \\
\text { (with base of } 1960 \text { ) }\end{array}$ & $\begin{array}{c}\text { MIECZKOWSKI } \\
\text { 1960-68 } \\
\text { (with base of 1960) }\end{array}$ \\
\hline $\begin{array}{l}\text { Aggregate consumption, including social } \\
\text { consumption }\end{array}$ & "almost 5 percent" & - \\
\hline Personal consumption & 4.0 & 3.5 \\
\hline $\begin{array}{l}\text { Less adjustments: } \\
\text { (1) Either: Rising employment } \\
\text { Or: Increase in the proportion of } \\
\text { economically active population } \\
\text { as a result of demographic } \\
\text { changes } \\
\text { Increased labor-force partici- } \\
\text { pation rate of women } \mathbf{b}\end{array}$ & 3.0 & 2.0 \\
\hline (2) Cost-of-living deflator & $1.0-1.5$ & $-c$ \\
\hline Total of adjustments (1) and (2) & $2.0-2.5[\text { sic }]^{\mathrm{d}}$ & 3.0 \\
\hline (3) Hidden price increases & not considered & 2.0 \\
\hline (4) Improvement in education & "at least 1 percent" & $\begin{array}{l}\text { not considered } \\
\text { separately }\end{array}$ \\
\hline Equals: & 0.5 & -1.5 \\
\hline (5) Increased incidence of overtime & 0.5 & not considered \\
\hline $\begin{array}{l}\text { Final estimate of annual change in the } \\
\text { average standard of living per "constant } \\
\text { worker" }\end{array}$ & 0.0 & -1.5 \\
\hline
\end{tabular}

a According to my own estimates covering the population outside agriculture, the proportion of active population rose from 51.7 percent in 1960 to 59.6 percent in 1969 , or by about 15 percent. For the economy as a whole, the not quite comparable census figures were 47.3 percent of the population employed in 1960, and 50.4 percent employed in 1970 . See W. Kawalec, "Narodowy spis powszechny 1970: Pierwsze rezultaty i pierwsze wnioski" [National Census 1970: First Results and Conclusions], Nowe Drogi, 1971, no. 4, pp. 37-38. I included in this adjustment an intuitive adjustment for improvement in the quality of the labor force, which was roughly equivalent to, but smaller than, Krencik's educational adjustment.

b The proportion of women in socialized employment rose from 33.2 percent in 1960 to 38.6 percent in 1968 , or by 16.3 percent. A similar change took place in the largely private agricultural sector.

c The 1.0 percent, assumed to have been included in the starting figure for the estimate of 3.5 percent, was obtained from $Z$. Żekoński, "Zmiany w strukturze spożycia w latach 1960-1968" [Changes in the Structure of Consumption During 1960-1968], Gospodarka Planowa, 1969, no. 11, p. 6. Żekoński's article contains much of the data underlying my estimate. The 1 percent estimate for the cost-of-living increase seems to be conservative. In a recent panel discussion J. Mujżel stated that during 1961-70 the cost of living rose by 1 to 3 percent annually. See "Ceny nie dają spokoju" (a panel discussion) [Prices Do Not Let Us Be], Zycie Gospodarcze, 1971, no. 48, p. 1.

d Krencik's sum of adjustments for rising employment and the cost of living in effect lowers the 3 percent annual rise in employment (shown by him in a different context in the same article) to a figure of only 1 percent, which belies his own statistics. According to Żekoński, "Zmiany w strukturze spożycia," p. 6, the average increase in employment was 3.4 percent between 1960 and 1968. 
neglected the effect of hidden inflation through assortment changes. $\mathrm{He}$ also, in my opinion, grossly underestimated the influence of demographic changes and of the rising labor-force participation, which I estimated at 3 percent and he, in effect, erroneously estimated at 1 percent. These differences between us account for his conclusion that real remuneration per worker was unchanged, while I arrived at a 1.5 percent annual rate of decrease. It ought to be stressed, however, that our procedures were roughly similar and that our conclusions supplement and corroborate each other. (For a comparison of our estimates see the table.)

There are, however, additional calculations which supplement and reinforce these estimates. The Polish journal devoted to statistical problems, Wiadomości Statystyczne, published an interesting partial indicator of the standard of living, in which the food component (defined as the proportion of the maximum satisfaction of nutritive needs) was described by a coefficient of 80.8 percent for $1960,80.2$ percent for 1965 , and 80.0 percent for $1970 .^{\circ}$ Thus the most important component of consumption, for which there is much unsatisfied demand, ${ }^{6}$ actually showed a declining degree of consumer wellbeing. One should note, however, that the study also arrived at an index of the standard of living which showed an unbelievable 19.6 percent increase between 1960 and 1970 . Housing, another important constituent of well-being, was found by an expert on that sector to be relatively less adequately satisfied in 1970 than in the bleak postwar year of 1950 , when much of the country still suffered from the effects of wartime destruction. ${ }^{7}$ Such conditions in the food and housing sectors, the two single most important components of material

5. See A. Luszniewicz's articles, "Przybliżona miara stopy życiowej ludności Polski" [An Approximate Measure of the Standard of Living of the Population in Poland], Wiadomości Statystyczne, 1970, no. 8, p. 10, and "Teoria i praktyka mierników poziomu życia ludności" [The Theory and Practice of the Measures of the Standard of Living of the Population], Gospodarka Planozer, 1971, no. 5, p. 262. Luszniewicz used a formula from J. Drewnowski, The Level of Living Index (Geneva: United Nations, 1966). His food indicator was based on nutritive components: $a_{1}=$ calories consumed; $a_{2}=$ consumption of proteins; $a_{3}=$ share of calories consumed not derived from starches. A decline in that index ( $100=$ maximum satisfaction) at low standard of living, and in view of Engel's law, in my opinion constitutes a valid indicator of decrease in the standard of living. The "Giffen paradox" could not have operated in Poland during the 1960s, and it would not have shown in the index arrived at by Luszniewicz, since the nutritive components chosen by him reflect "quality food."

6. This is indicated by an income elasticity of demand for food of 0.77 , and by the fact that almost 50 percent of consumer expenditures are spent on foodstuffs. See my "Recent Discussion on Consumption Planning in Poland," cited above, and the background calculations for my article "The Polish Index of Consumption, 1938-1964," Bentley Business and Economic Review, June 1969.

7. E. Rychlewski, "Długookresowy popyt mieszkaniowy" [Long-Term Demand for Housing], Ekonomista, 1970, no. 6, p. 1172 (Ekonomista is the journal of the Polish Economic Society). 
well-being, could hardly have contributed to worker satisfaction. They may have been one of the reasons why the Polish Central Statistical Office was disinclined to publish adequate data on changes in consumption and real wages.

Polish economists are not unaware of the conclusions inherent in the present note. A statement published in connection with the Sixth Party Congress (December 1971) mentions that an increase in family incomes was attained during the past period mainly through an increase in the number of family members employed, and not through an increase in the real wages of the main income earner. The statement adds that a radical improvement in the material situation of low-income families was possible in practice only through the early employment of working-age children. ${ }^{8}$ Two other authors note that "since a weak rate of growth of the standard of living of the population has been maintained since 1959, or for eleven years, a radical acceleration of that growth seems necessary during the current Five-Year Plan." In this connection, a resolution of the Polish Economic Society, passed in 1971, stated that "faster growth of consumption is currently, and will be in the future, a condition for attaining a higher rate of growth of production. Without an adequate growth of consumption, the expanding capacity of the economy is not linked to the goal of production, and the mechanism of growth creates 'production for the sake of production,' which slows down the general rate of growth."10 Thus, proper conclusions seem to have been drawn from the analysis of the 1960-70 period.

The data and estimates provided above constitute a contribution to a better understanding of the reasons for the bloody riots of December 1970 in Poland, and for the strikes which continued into January of 1971. They also indicate that the "direct goal" (quoted at the beginning of this note) of supplying "increasingly abundant amounts of consumer goods" was somewhat less than perfectly achieved in Poland during the 1960s. It will be interesting to see whether the new Gierek regime can change the past trend in workers' real wages, deflated to the measure of per worker and per unit of contribution to production. If it succeeds in this policy, a potent source of workers' dissatisfaction will have been removed.

8. S. Chełstowski, "Wybór celów" [Selection of Goals], Życie Gospodarcze, 1971, no. 45, p. 2.

9. H. Król and Z. Drozdek, "Problemy społeczne w planowaniu gospodarczym" [Social Problems in Economic Planning], Nowe Drogi, 1971, no. 9, p. 36.

10. "Uchwała Krajowego Zjazdu Ekonomistów" [Resolution of the National Congress of Economists], Ekonomista, 1971, no. 3, p. 354. 